\title{
Non-Metrical Variation in the Skull of Norwegian Lynx
}

\author{
Øystein WIIG ${ }^{1}$ \& Trond ANDERSEN
}

\begin{abstract}
Wiig Ø. \& Andersen T. 1988: Non-metrical variation in the skull of Norwegian lynx. Acta theriol., 33, 1: 3-19. [With 4 Tables \& 1 Fig.]

The variation of 53 non-metrical variants in the skull of 50 male and 50 female Norwegian lynx Lynx lynx (Linnaeus, 1758) were examined. The variants are described in detail, and the range of the variation of each variant is tabulated. A significant association between left and right side in bilateral variants were obtained in more than $50 \%$ of the variants, indicating that incidence of the variants on each side can not be pooled. Sex-, size-, and age-dependence of the variants were studied based on the incidence from one side only (the left), but few significant results were obtained. Correlation between each of the 1378 pairs of variants was calctilated and 107 of them $(7.8 \%)$ were found to be significant.
\end{abstract}

[Dept. of Systematic Zoology, Zoological Museum, Univ. of Bergen, N-5007 Bergen, Norway]

\section{INTRODUCTION}

The use of non-metrical variants (also known as quasicontinuous variables or epigenetic polymorphism) as genetical markers in mammalian population studies, is a well established technique (e.g. Berry, 1969a,b; Berry \& Warwick, 1974; Sjøvold, 1977; Berry, Jacobson \& Peters, 1978; Andersen \& Wiig, 1982; Wiig \& Lie, 1984; Pankakoski \& Nurmi 1986; Berry, 1986). The value of non-metrical variants for population studies was first evident in genetical studies of inbred stocks of laboratory mice (reviewed by Grüneberg, 1963). Self \& Leamy (1978) found the heritability of non-metrical variants to be significantly different from zero in randomly bred mice.

The variants are believed to be caused by the accumulating effects of a high number of alleles acting at several loci, as well as of various non-genetic factors. It seems therefore reasonable to assume that the total effect, called liability (Falconer, 1981) is normally distributed (Sjøvold, 1977). A variant is manifested when its liability exceeds the threshold [see Falconer (1981) for discussion of threshold characters].

Each variant may be presumed to be under the control of at least ten gene loci (Berry \& Jacobson, 1975; Berry, 1986) and they are usually

\footnotetext{
${ }^{1}$ Present address: Norwegian Polar Research Institute, P.O.Box 158, N-1330 Oslo Lufthavn, Norway.
} 
uncorrelated with each other (Truslove, 1961; Sjøvold, 1977), indicating that different variants are controlled by different loci.

Often non-metrical variants appear in more than two states, e.g. a foramen may be absent, single, double, triple etc., which indicate the existence of more than one threshold on the liability axis. However, the mathematical properties of multistate characters have not been solved (e.g. Sjøvold, 1977), and thus several states have been pooled to obtain only two alternatives (i.e. absent versus present) when a mean measure of divergence has been calculated in population studies.

Among the assumptions behind the use of non-metrical variants in population studies are that they are uncorrelated, independent of sex and that the correlation between sides in bilateral variants is negligible. These assumptions have, however, been proven to fail for particular traits (e.g. Sjøvold, 1977).

In the present study we examine the variation of 53 non-metrical variants in the skull of 50 male and 50 female Norwegian lynx.

\section{MATERIAL AND METHODS}

\subsection{Material}

The study is based on 100 complete skulls ( 50 males and 50 females) from the material earlier described by Andersen \& Wiig (1984) and Wiig \& Andersen (1986). The animals have been hunted in most parts of Norway, but mainly in the counties of Sør-Trøndelag, Nord Trøndelag, Nordland, and Troms, during the ten-year period 1960 to 1969. The carcasses were sent to The Norwegian Game Research (DN Viltforskningen) in order to collect a shooting reward. The skeletons are now deposited at the Zoological Museum, University of Bergen.

The specimens have been sex-identified from internal sex-organs and aged from incremental annuli in the cementum of the canine tooth root as described by Reimers \& Nordby (1968) at the Norwegian Game Research. The ages of specimens younger than 1.5-2 years, when the first dark zone in the tooth root is formed, were set to the number of months between an estimated date of birth (15 May) to the date of capture, allowing for two age classes (Kvam, 1979, 1983, 1984).

The age of the male skulls in the present study range from 19 to 95 months while the age of the female skulls range from 4 to 91 months.

\subsection{Non-metrical Variants}

The following 53 non-metrical variants were analysed, Fig. 1 . The variants are listed in relation to the different bones of the skull where they are situated. The variants are regarded as bilateral if not otherwise stated.

Occipitale:

1. Occipital fenestra - A non-ossified area in the supraoccipital region above foramen magnum. 
2. Dorasal condylar foramen - A small vascular foramen situated dorsal to the occipital condyles.

3. Lateral condylar foramen - A distinct foramen situated in the lateral margin of foramen magnum, at the base of the condyle.

4. Interior condylar foramen - A distinct foramen situated endocranially anterior to the lateral margin of foreman magnum.

5. Accessory hypoglosal foramen - A small vascular foramen sitting in the paraoccipital ridge posterior to the hypoglosal foramen.

6. Hypoglosal foramen open - Sometimes the posterior margin of the hypoglosal foramen forms an open canal through the paraoccipital ridge. In juveniles the opening of the hypoglosal foramen is large, the passage to the interior of the braincase clearly visible, and the exterior canal usually present. In adults the paraoccipital ridge is stronger and the canal more often absent.

Interparietale:

7. Cerebellar tentorium fenestra - An un-ossified area in the ventral part of the osseus cerebellar tentorium, (not figured).

Frontale:

8. Posterior frontal foramen - A small foramen situated on the dorsal surface of frontale posterior to the temporal crest.

9. Posterior postorbital foramen - A small vascular foramen situated on the posterior surface of the postorbital process.

10. Postorbital foramen - A small vascular foramen situated on the dorsal surface of the postorbital process.

11. Anterior frontal foramen - A distinct foramen situated on the anteroventral surface of the postorbital process.

12. Ethmoidal foramen - A large foramen situated in the orbital part of frontale.

13. Accessory ethmoidal foramen - A small distinct foramen situated in the orbital part of frontale immediately above the ethmoidal foramen.

Temporale:

14. Mastoid foramen - A vascular foramen situated on the dorsal surface of the mastoid crest.

15. Basal zygomatic foramen - A vascular foramen situated on the dorsal surface of the base of the zygomaticum.

16. Postglenoid foramen - A small distinct foramen situated at the base of the postglenoid process immediately anterior to the tympanic bulla.

17. Postglenoid foramen separate - The foramen is often situated in the suture between the postglenoid process and the tympanic bula.

18. Mandibular fossa foramen - A small vascular foramen situated interior in the mandibular fossa.

\section{Alisphenoid:}

19. Dorsal alisphenoid foramen - A small distinct foramen situated in the wing of alisphenoid near the suture with the squamosal part of temporale and parietale.

20. Ventral alisphenoid foramen - A small distinct foramen situated at the base of the wing of alisphenoid. 
$\infty$

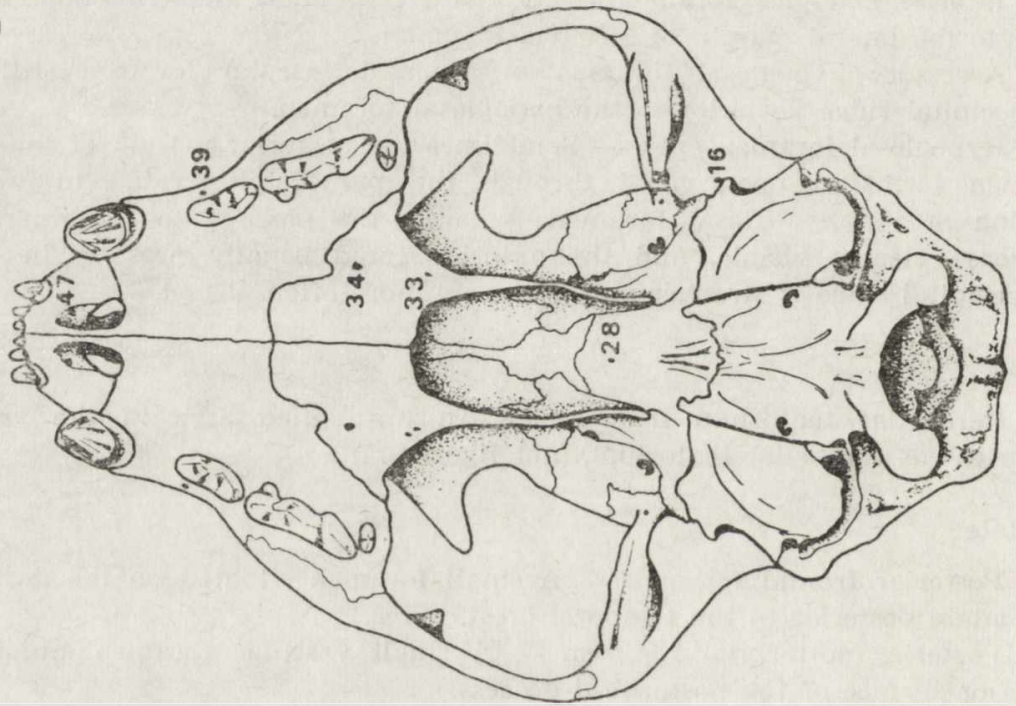

$\varangle$

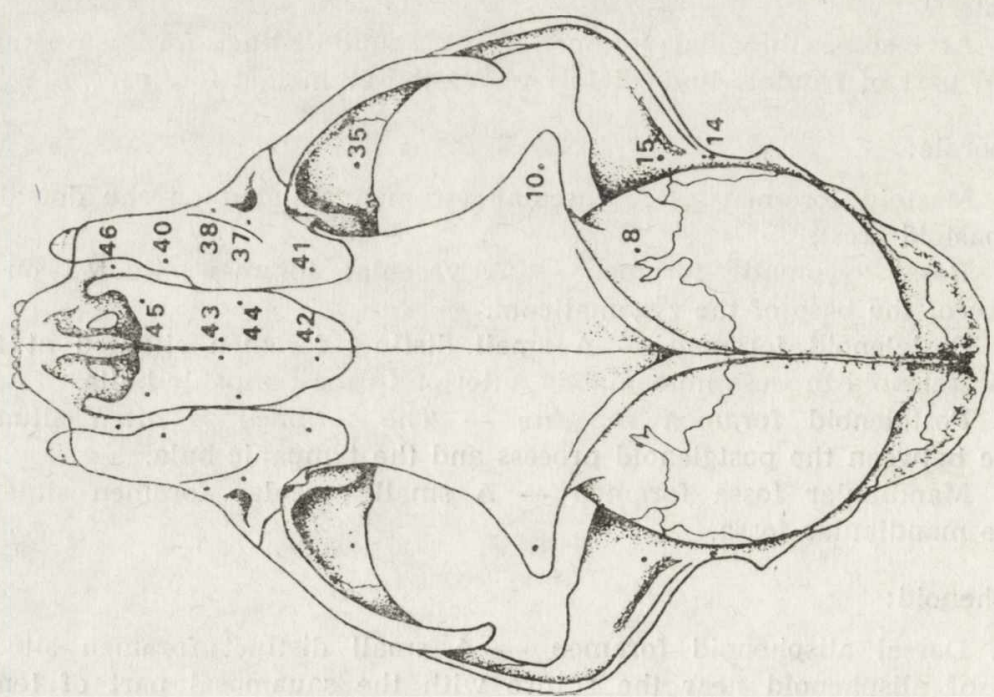


C
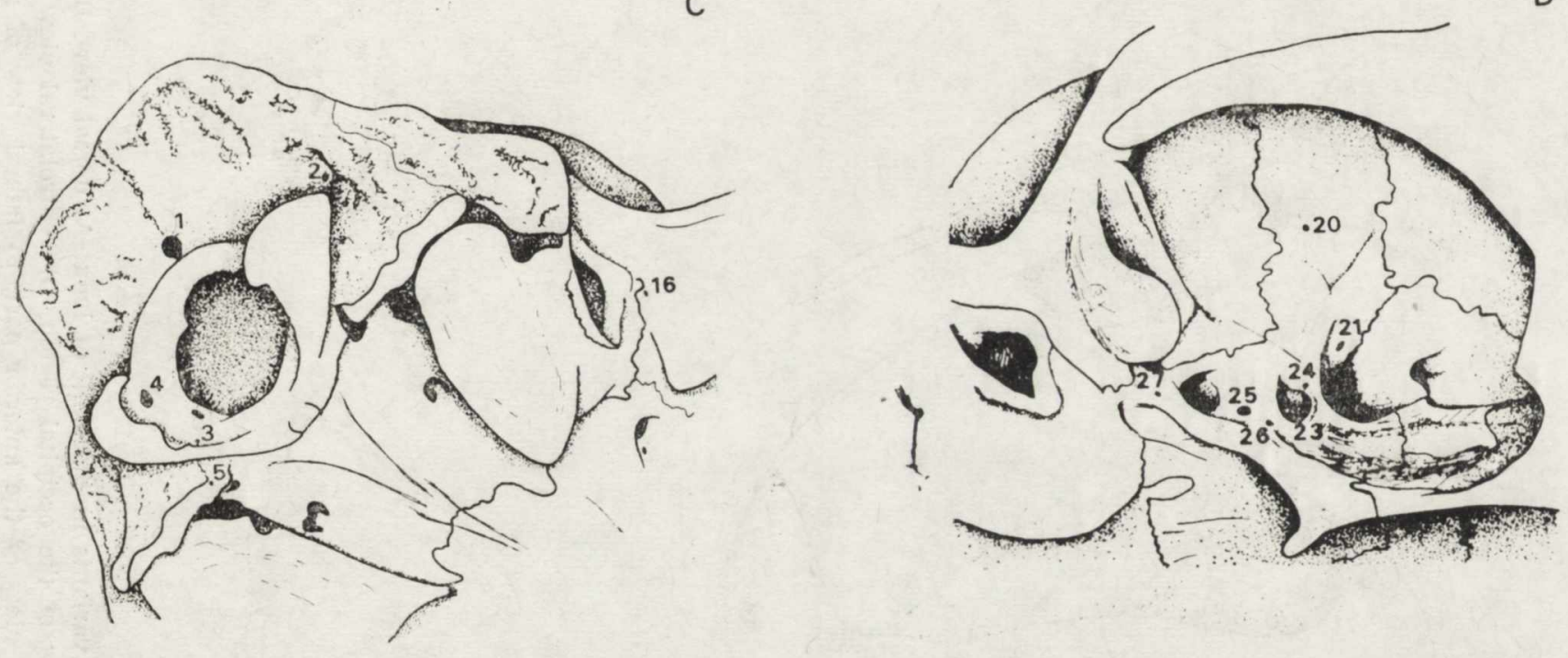

Fig. 1. See p. 8 for explanation. 

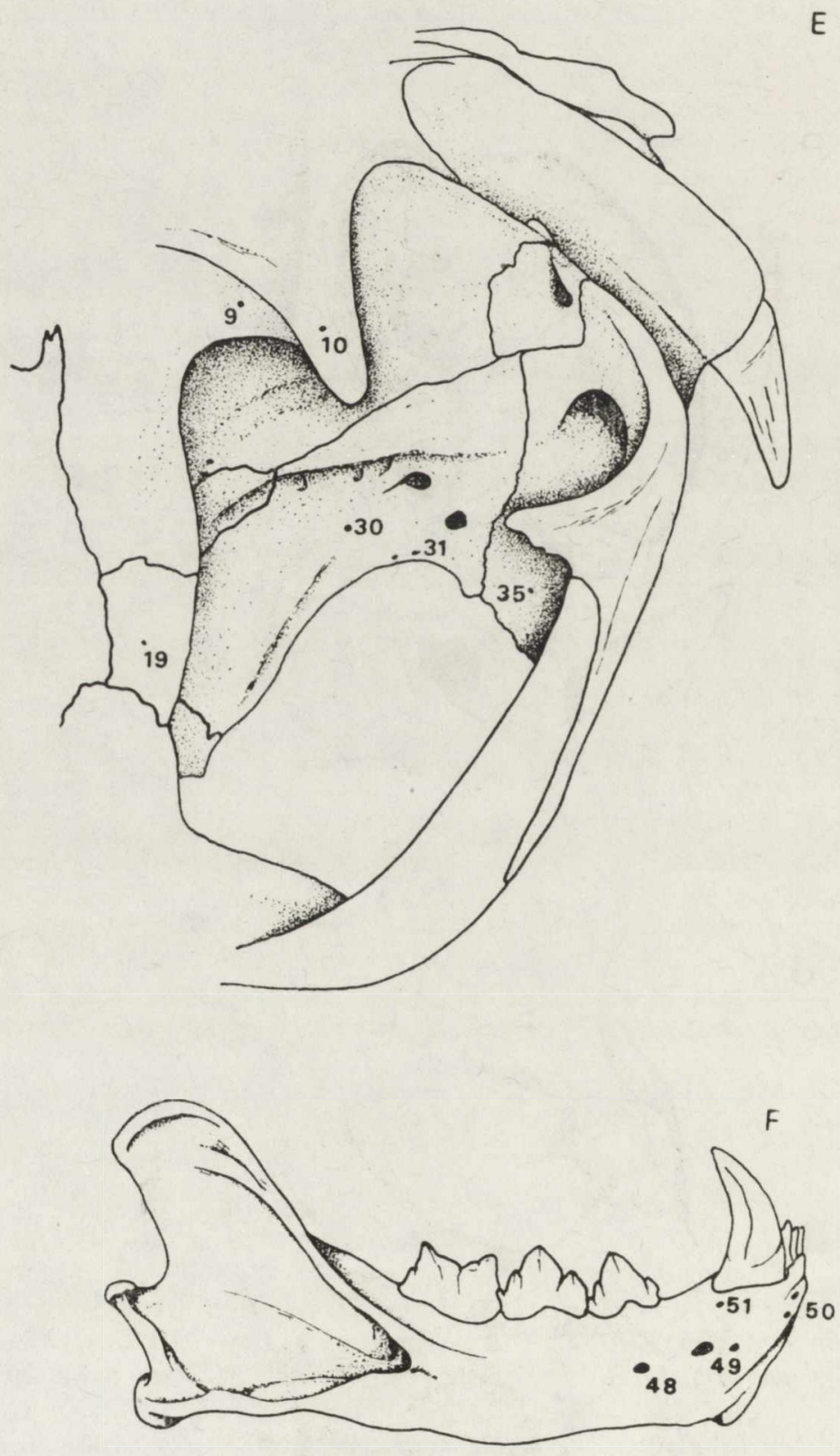

Fig. 1. Non-metrical variants in the skull of lynx. A) dorsal view, B) ventral view, C) ventrolateral view of the occipital region, D) ventrolateral view of the middle part, E) dorsolateral view of the anterior part, F) lateral view of right mandible. See tert for names and definitions. 
21. Accessory lacerate foramen - A small foramen situated in the dorsal margin of the anterior lacerate foramen.

22. Accessory lacerate foramen separate - The foramen is often situated in the suture between alisphenoid and presphenoid.

23. Foramen rotundum divided - A small foramen situated in the back wall of foramen rotundum, just inside the opening.

24. Accessory foramen rotundum - A distinct foramen sitvated in the wall outside the opening of foramen rotundum. In most cases the foramen forms a canal opening into foramen rotundum.

25. Foramen ovale minor - The foramen ovale minor is situated anterior to foramen ovale.

26. Accessory foramen ovale minor - A small foramen situated anterior to foramen ovale minor at the base of the pterygoid bone.

27. Accessory foramen ovale - A small vascular foramen situated between the posterior margin of foramen ovale and the suture between alisphenoid and the tympanic bulla.

Basisphenoid:

28. Median basisphenoid foramen - A small distinct foramen sitting in the median line on the ventral surface of basisphenoid. Unilateral trait.

29. Internal basisphenoid foramen - A distinct foramen situated endocranially in the posterior part of basisphenoid.

Palatinum:

30. Posterior palatine foramen - A tiny foramen situated on the exterior surface of the perpendicular part of the palatine bone. The opening of the foramen is usually round.

31. Anterior palatine foramen - A small foramen situated along the anterior part of the ventrolateral edge of the perpendicular part of the palatine bone. The opening of the foramen is somewhat triangular, the canal penetrating anteriorly.

32. Accessory caudal palatine foramen - A small distinct foramen situated in the opening of the caudal palatine foramen.

33. Minor palatine foramen - A small distinct foramen situated in the posteriolateral part of the horizontal plate of the palatine bone.

34. Major palatine foramen - A large foramen situated in the anterio-lateral part of the horizontal plate of the palatine bone.

Maxillare:

35. Posterior maxillary foramen - A vascular foramen situated above the alveolus of the third molar.

36. Infraorbital foramen - The infraorbital foramen can be double.

37. Maxillary foramen I - A tiny distinct foramen situated on the nasal surface of maxillare near the ridge above the infraorbital foramen.

38. Maxillary foramen II - A tiny distinct foramen situated on the nasal surface of the maxilla near the ridge below the infraorbital foramen.

39. Maxillary foramen III - A tiny, vascular foramen situated above the first premolar.

40. Maxillary foramen IV - A small distinct foramen situated in the nasal surface of the maxillare along the suture between maxillare and nasale and between maxillare and the upper part of the nasal process of premaxillare. 
41. Maxillary foramen V - A small distinct foramen situated in the median part of the nasal surface of the maxillare.

Nasale:

42. Nasal foramen I - A small distinct foramen situated in the upper part of nasale.

43. Nasal foramen II - A small distinct foramen situated in the middle part of nasale near the median margin.

44. Nasal foramen III - A small distinct foramen situated in the middle part of nasale near the lateral margin.

45. Nasal foramen IV - A small distinct foramen situated in the lower part of nasale.

Premaxillare:

46. Dorsal premaxillary foramen - A small distinct foramen situated in the nasal process of premaxillare.

47. Accesory anterior palatine foramen - A small vascular foramen situated anterior to the palatine foramen.

Mandibulare:

48. Posterior mental foramen - A distinct foramen sitting posterior to the mental foramen.

49. Mental foramen - The foramen is usually single, but two, three or even four foramina can be present.

50. Anterior mental foramen - A somewhat smaller foramen sitting at the base of the incisors, anterior to the mental foramen.

51. Canine foramen - A small foramen sitting at the base of the canine, above the mental foramen.

52. Accessory mandibular foramen - A small foramen sitting lingually at the base of the angular process behind the mandibular foramen.

53. $\mathbf{M}_{2}$ - The second molar in the lower jaw is sometimes present.

\subsection{Statistical Analyses}

The statistical tests applied in the present work are all based on two-way contigency tables which are analysed by help of the computer program BMDP $4 \mathrm{~F}$ (Dixon, 1981).

The homogeneity of the variants' appearance with respect to sex were tested by Fisher's exact test when tables were $2 \times 2$ and the minimum expected cell valce was less than 20 . In the other cases the likelihood ratio chi-square statistic $\mathrm{G}^{2}$ based on maximum likelihood estimation were applied.

The remaining tests in the present work are tests of association. These are tests of lateral manifestation in bilateral variants, tests of association with size and age, and tests of the correlation between the states of appearance of pair of variants. When testing for size correlations the skulls within each sex were grouped in ten size classes with equal size range, using the condylobasal length as size variable. In the same manner the correlation with age was tested, but in this case the sexes were pooled.

All these tests were computed from Spearman's rank correlation coefficient, 
Table 1

Frequences of non-metrical variants in the skull of 50 male and 50 female Norwegian lynx Lynx lynx.

\begin{tabular}{|c|c|c|c|c|c|c|c|c|c|c|c|c|}
\hline \multirow{2}{*}{$\begin{array}{c}\text { Variant } \\
\text { no. }\end{array}$} & \multicolumn{6}{|c|}{ Males } & \multicolumn{6}{|c|}{ Females } \\
\hline & 0 & 1 & 2 & 3 & 4 & 5 & 0 & 1 & 2 & 3 & 4 & 5 \\
\hline 1 & 94 & 6 & & & & & 96 & 4 & & & & \\
\hline 2 & 3 & 35 & 47 & 15 & & & 3 & 51 & 41 & 3 & 2 & \\
\hline 3 & & 99 & 1 & & & & & 91 & 9 & & & \\
\hline 4 & & 95 & 5 & & & & & 93 & 7 & & & \\
\hline 5 & 82 & 17 & 1 & & & & 84 & 14 & 2 & & & \\
\hline 6 & 75 & 25 & & & & & 69 & 31 & & & & \\
\hline 7 & 91 & 9 & & & & & 96 & 4 & $4=$ & & & \\
\hline 8 & 35 & 50 & 12 & 2 & 1 & & 35 & 47 & 14 & 3 & 1 & \\
\hline 9 & 48 & 49 & 3 & & & & 40 & 53 & 7 & & & \\
\hline 10 & 38 & 57 & 4 & 1 & & & 45 & 48 & 7 & & & \\
\hline 11 & & 63 & 35 & 2 & & & & 65 & 32 & 3 & & \\
\hline 12 & & 82 & 18 & & & & & 84 & 16 & & & \\
\hline 13 & 20 & 40 & 29 & 9 & 1 & 1 & 47 & 42 & 7 & 4 & & \\
\hline 14 & 14 & 39 & 34 & 10 & 2 & 1 & 25 & 39 & 30 & 6 & & \\
\hline 15 & 29 & 52 & 17 & 2 & & & 54 & 37 & 8 & 0 & 1 & \\
\hline 16 & 10 & 84 & 6 & & & & 7 & 86 & 6 & 1 & & \\
\hline 17 & 45 & 53 & 2 & & & & 28 & 72 & & & & \\
\hline 18 & 57 & 36 & 6 & 1 & & & 69 & 28 & 3 & & & \\
\hline 19 & 59 & 30 & 11 & & & & 60 & 26 & 12 & 2 & & \\
\hline 20 & 12 & 55 & 25 & 7 & 1 & & 10 & 54 & 31 & 5 & & \\
\hline 21 & & 92 & 7 & 1 & & & 2 & 92 & 6 & & & \\
\hline 22 & 50 & 47 & 3 & & & & $5 \overline{3}$ & 47 & & & & \\
\hline 23 & 1 & 73 & 26 & & & & 2 & 76 & 22 & & & \\
\hline 24 & 86 & 14 & & & & & 90 & 10 & & & & \\
\hline 25 & 35 & 65 & & & & & 22 & 78 & & & & \\
\hline 26 & 46 & 52 & 2 & & & & 51 & 46 & 3 & & & \\
\hline 27 & 90 & 10 & & & & & 92 & 8 & & & & \\
\hline 28 & & 62 & 38 & & & & & 52 & 46 & 2 & & \\
\hline 29 & 34 & 57 & 9 & & & & 39 & 57 & 4 & & & \\
\hline 30 & 25 & 59 & 15 & 1 & & & 25 & 60 & 14 & 1 & & \\
\hline 31 & 85 & 15 & & & & & 73 & 26 & 1 & & & \\
\hline 32 & & 61 & 31 & 8 & & & & 69 & 28 & 2 & 1 & \\
\hline 33 & 32 & 58 & 10 & & & & 23 & 54 & 20 & 3 & & \\
\hline 34 & 1 & 22 & 64 & 12 & 1 & & & 28 & 58 & 14 & & \\
\hline 35 & 2 & 63 & 32 & 3 & & & 1 & 53 & 43 & 3 & & \\
\hline 36 & & 94 & 4 & & & & & 98 & 2 & & & \\
\hline 37 & 8 & 71 & 15 & 2 & 1 & 3 & 11 & 70 & 16 & 1 & 0 & 2 \\
\hline 38 & 1 & 30 & 27 & 30 & 11 & 1 & 6 & ?? & 33 & 27 & 11 & 1 \\
\hline 39 & 17 & 35 & 35 & 8 & 4 & 1 & 13 & 42 & 34 & 10 & n & 1 \\
\hline $4 n$ & 8 & 42 & 40 & 8 & 2 & & 13 & 57 & 20 & 7 & 3 & \\
\hline 41 & 48 & 49 & 2 & 1 & & & 45 & 54 & 1 & & & \\
\hline 42 & 59 & 41 & & & & & 63 & 37 & & & & \\
\hline 43 & 53 & 46 & 1 & & & & 59 & 48 & & & & \\
\hline 44 & 70 & 30 & & & & & 66 & 34 & & & & \\
\hline 45 & 75 & 24 & 1 & & & & 71 & 90 & & & & \\
\hline 46 & 1 & 87 & 12 & & & & 4 & 89 & 7 & & & \\
\hline 47 & 40 & 46 & 11 & 2 & 1 & & 65 & 97 & 8 & & & \\
\hline 48 & & 88 & 11 & 1 & & & & 87 & 13 & & & \\
\hline 49 & & 59 & 31 & 9 & 1 & & & 57 & 36 & 6 & 1 & \\
\hline 50. & & 39 & 56 & 5 & & & & 45 & $5 ?$ & 2 & 1 & \\
\hline 51 & 74 & 24 & ? & & & & $7 n$ & 94 & G & & & \\
\hline 59 & 5n & 48 & 2 & & & & $\Delta A$ & 54 & 2 & & & \\
\hline 53 & 83 & 17 & & & & & 93 & 7 & & & & \\
\hline
\end{tabular}


which give greater weight to pairs of ranks that are further appart, if the true correlation is different from zero. The correlations were tested for significance by the ratio of the estimated correlation to its approximate assymptotic standard error. This ratio is approximately $t$-distributed provided the correlation is zero (Brown \& Benedetti, 1977).

Further descriptions of the statistics used are found in Dixon (1981) and Sokal \& Rohlf (1981).

\section{RESULTS}

The incidence of the variants based on the side as unit with regard to bilateral traits, are set out in Table 1. As can be seen, most of the variants have more than two states, i.e. are multistate variants.

Correlation of lateral manifestation in bilateral variants are shown in Table 2. A significant association between left and right side were obtained in more than $50 \%$ of the variants. The level of significance is

Table 2

Correlation between sides of bilateral non-metrical variants in the skull of 100 Norwegian lynx Lynx lynx (sexes pooled).

\begin{tabular}{rlcl}
\hline Variant no. & Spearman's $r$ & Variant no. & Spearman's $r$ \\
\hline 1 & $1.000^{*}$ & & \\
2 & 0.185 & 28 & $1.000^{* * *}$ \\
3 & 0.185 & 29 & $0.523^{* * *}$ \\
4 & 0.291 & 30 & $0.205^{*}$ \\
5 & 0.078 & 31 & 0.175 \\
6 & $0.455^{* * *}$ & 32 & 0.162 \\
7 & $0.523^{* * *}$ & 33 & 0.163 \\
8 & $0.462^{* * *}$ & 34 & -0.007 \\
9 & $0.320^{* * *}$ & 35 & $0.245^{*}$ \\
10 & $0.220^{*}$ & 36 & 0.265 \\
11 & 0.025 & 37 & 0.254 \\
12 & $0.293^{* * *}$ & 38 & $0.459^{* * *}$ \\
13 & $0.581^{* * *}$ & 39 & $0.421^{* * *}$ \\
14 & $0.443^{* * *}$ & 40 & $0.241^{*}$ \\
15 & $0.412^{* * *}$ & 41 & $0.202^{*}$ \\
16 & 0.135 & 42 & $0.331^{* * *}$ \\
17 & $0.508^{* * *}$ & 43 & 0.089 \\
18 & $0.168^{* * *}$ & 44 & 0.037 \\
19 & $0.494^{* * *}$ & 45 & 0.305 \\
20 & $0.399^{* * *}$ & 46 & $0.236^{*}$ \\
21 & 0.085 & 47 & 0.229 \\
22 & 0.185 & 48 & 0.014 \\
23 & $0.500^{* * *}$ & 49 & $0.388^{* * *}$ \\
24 & 0.173 & 50 & 0.049 \\
25 & 0.167 & 51 & 0.158 \\
26 & $0.304^{*}$ & 52 & $0.341^{*}$ \\
27 & 0.065 & 53 & \\
\hline
\end{tabular}

${ }^{*} p<0.05 ; \quad{ }^{* * *} p<0.001$. 
in most cases $0.1 \%$ with correlation coefficients nearly as high as 0.60 . Thus the incidence of the variants on each side simply can not be pooled. Accordingly, most of the tests in the present paper are based on the incidence from one side only (the left).

Tests of sex dependence of the variants were based on the data from the left side. Variants No. 13, 15, 17, and 32 were found to have a different distribution in the two sexes $(p<0.05$ for all). This is only slightly more than can be attributed to chance, thus in the rest of the tests the sexes were kept pooled if not otherwise stated.

Table 3

Correlation between state of appearance of non-metrical variants and condylobasal length in Norwegian lynx Lynx lynx older then 18 month.

\begin{tabular}{rrrrrr}
\hline $\begin{array}{c}\text { Trait } \\
\text { no. }\end{array}$ & Males & Females & $\begin{array}{c}\text { Trait } \\
\text { no. }\end{array}$ & Males & Females \\
\hline 1 & 0.161 & 0.130 & 28 & -0.234 & -0.075 \\
2 & 0.009 & 0.056 & 29 & 0.106 & -0.115 \\
3 & 0.000 & 0.130 & 30 & $0.458 * *$ & -0.018 \\
4 & 0.260 & -0.189 & 31 & 0.046 & 0.006 \\
5 & 0.110 & 0.285 & 32 & 0.025 & 0.061 \\
6 & 0.038 & 0.070 & 33 & -0.008 & -0.071 \\
7 & -0.153 & 0.000 & 34 & -0.044 & 0.242 \\
8 & 0.195 & 0.088 & 35 & $0.334^{*}$ & -0.093 \\
9 & 0.002 & -0.122 & 36 & -0.073 & -0.035 \\
10 & 0.068 & -0.127 & 37 & $0.287 *$ & 0.253 \\
11 & -0.191 & 0.260 & 38 & 0.085 & -0.012 \\
12 & 0.000 & -0.005 & 39 & 0.060 & 0.138 \\
13 & 0.189 & 0.266 & 40 & 0.037 & -0.083 \\
14 & 0.125 & 0.140 & 41 & -0.102 & 0.125 \\
15 & 0.010 & 0.038 & 42 & 0.189 & -0.148 \\
16 & -0.206 & 0.211 & 43 & 0.017 & -0.193 \\
17 & -0.092 & -0.065 & 44 & -0.153 & 0.225 \\
18 & -0.095 & -0.006 & 45 & 0.013 & -0.141 \\
19 & 0.238 & 0.152 & 46 & -0.260 & -0.184 \\
20 & 0.109 & 0.073 & 47 & -0.060 & -0.142 \\
21 & 0.101 & -0.161 & 48 & -0.078 & -0.134 \\
22 & -0.202 & 0.006 & 49 & -0.058 & -0.184 \\
23 & -0.061 & 0.114 & 50 & -0.029 & 0.214 \\
24 & -0.036 & -0.123 & 51 & -0.078 & -0.243 \\
25 & -0.135 & -0.253 & 52 & -0.143 & -0.229 \\
26 & -0.058 & -0.115 & 53 & 0.134 & 0.031 \\
27 & -0.241 & -0.159 & & & \\
\hline
\end{tabular}

* $p<0.05 ; \quad$ *** $p<0.001$.

As sexual size dimorphism in the skull of lynx has been demonstrated (Andersen \& Wiig, 1984; Wiig \& Andersen, 1986), the sexes were kept separate when correlations with condylobasal length were computed. In the males, three of the correlations turned out to be significant (No. 30, No. 35 , and No. 37 , Table 3 ).

In females, four of the variants were found to be significantly correlated to the condylobasal length: No. $5(r=0.353, p<0.05)$, No. 13 
$(r=0.471, p<0.01)$, No. $23(r=0.307, p<0.05)$, and No. $52(r=-0.332$, $p<0.05$ ). By restricting the computations to females older then 18 months, however, the correlations decreased considerably and none turned out to be significant (Table 3).

Based on the whole sample, eight variants were found to be correlated with age: No. $8(r=0.405, p<0.001)$, No. $10(r=-0.204, p<0.05)$, No. 12 $(r=-0.254, p<0.05)$, No. $15(r=0.200, p<0.05)$, No. $19(r=0.244, p<0.05)$, No. $30(r=0.248, p<0.05)$, No. $37(r=0.318, p<0.001)$, and No. $42(r=$

Table 4

Rank-correlation between state of appearance of non-metrical variants and age in the skull of male and female Norwegian lynx Lynx lynx between 18 and 100 months old $(n=81)$.

\begin{tabular}{cccc}
\hline Trait no. & Correlation & Trait no. & Correlation \\
\hline 1 & 0.116 & 28 & -0.102 \\
2 & 0.033 & 29 & 0.040 \\
3 & 0.028 & 30 & $0.338 * *$ \\
4 & 0.234 & 31 & 0.034 \\
5 & 0.101 & 32 & 0.188 \\
6 & -0.055 & 33 & 0.054 \\
7 & -0.106 & 34 & 0.161 \\
8 & $0.483 * * *$ & 35 & 0.133 \\
9 & -0.062 & 36 & 0.061 \\
10 & -0.093 & 37 & 0.271 \\
11 & -0.128 & 38 & 0.108 \\
12 & -0.134 & 39 & 0.130 \\
13 & 0.066 & 40 & 0.058 \\
14 & 0.148 & 41 & 0.166 \\
15 & 0.183 & 42 & 0.006 \\
16 & -0.118 & 43 & 0.081 \\
17 & -0.251 & 44 & 0.019 \\
18 & 0.158 & 45 & 0.139 \\
19 & 0.222 & 46 & 0.068 \\
20 & 0.092 & 47 & 0.021 \\
21 & 0.022 & 48 & 0.126 \\
22 & -0.177 & 49 & $0.222 *$ \\
23 & -0.168 & 50 & 0.056 \\
24 & 0.004 & 51 & 0.082 \\
25 & -0.077 & 52 & 0.092 \\
26 & 0.104 & 53 & \\
27 & -0.040 & & \\
\hline
\end{tabular}

${ }^{*} p<0.05 ; \quad * * p<0.01 ; \quad{ }^{* * *} p<0.001$.

$=0.246, p<0.05$ ). By restricting the tests to specimens older than 18 months so that the age range of both sexes were equal, the number of significant correlations was lowered to three (Table 4).

The correlation between each of the 1378 pairs of variants was calculated and 107 of them (7.8\%) were found to be significant $(p<0.05)$, which is a higher number than can be ascribed to chance alone. Fifty of the correlations were negative and 57 were positive, what seems to be at random. Most of the correlations ranged in absolute size from 0.1 to 
0.3 , but five of the correlations were highly significant $(p<0.001)$ and ranged higher. These were between variant Nos. 14 and $15(r=0.34)$ and Nos. 16 and $17(r=0.36)$ in temporale, between No. 16 in temporale and No. 22 in alisphenoid $(r=0.31)$, between Nos. 31 and $33(r=0.28)$ and between Nos. 32 and $34(r=0.34)$ in palatinum.

\section{DISCUSSION}

More than 50 non-metrical variants have been recognized in the skeleton of laboratory mice (e.g. Berry \& Searl, 1963). It has been assumed that differences in the incidences of these variants among wild populations reflected genetic differences. Self \& Leamy (1978) studied the heritability of eleven of these variants in a randomly bred population and found the heritability to be rather low but significantly different from zero. Analogous variants have been used in other species, with the assumption that they have the same genetical basis as those studied in laboratóry mice.

In earlier studies of non-metrical variation, the variants have been recorded as if they only appear in two states. The results of the present study clearly demonstrate the multistate nature of the variants, indicating more than one threshold on the liability scale. In most variants the frequency of extreme states are, however, very low. In some cases where a variant consists of four or more foramina, the scoring can be difficult and, as a result, the distinction between these extreme states might be uncertain.

A tendency of symmetry in bilateral variants seems to exist, but the number of significant symmetric expressions found may be strongly influenced by sample size (Sjøvold, 1977), or environmental factors (Pankakoski, 1985). In the study of third molar loss in laboratory mice, Grüneberg (1963) pointed out that the unit of variation was not the individual tooth but the mouse as a whole. Usually, however, the incidence of bilateral variants is based on the individual side as a unit (e.g. Grewal, 1962; Berry, 1975). In the present study very high correlations between sides in most of the bilateral variants were found, indicating that the expression of a particular trait in the left and right side are affected by the same genes. Therefore, when testing for age, size and sex dependence, we used the incidence on the left side only.

The incidence of non-metrical variants are usually found to be largely independent of sex (e.g. Berry \& Jackobson, 1975; Wiig \& Lie, 1979). However, Sjøvold (1977) and Wiig \& Lie (1984) found significant differences between the sexes in several variants in other mammals. In the present study only four variants had a different distribution in the 
two sexes, a number only slightly greater than can be ascribed to chance alone.

According to the model advocated by Grüneberg (1963) the liability of non-metrical variants is metric in nature, and correlation with size can be expected (Sjøvold, 1977; Pankakoski \& Nurmi, 1986). In males, only three significant correlations with the condylobasal length were detected at a $5 \%$ level, a number which is what could be expected by chance. However, the correlation with the state of appearance of posterior palatin foramen was highly significant $(p<0.001)$ and cannot be ascribed to the chance effects.

In females several more significant correlations were found, which is only natural since the female sample contained younger specimens than the male sample. Andersen \& Wiig (1984) demonstrated that the size change of the lynx skull is particulary large during the first year and a half. Restricting females to the same age range as males revealed no significant correlation with size. Correlation with size could explain sex dependent distribution of variants (Pankakoski \& Nurmi, 1986). A test for sex dependence excluding females less than 18 months gave, however, significant differences between the sexes in the same variants.

Size dependent manifestation of non-metrical variants may have two different causes (Sjøvold, 1977; Hartman, 1980; Hanski \& Kuitunen, 1986). The changes in incidence may be either a direct function of size, or a function of genetical differences between small and large specimens within each sex.

Age, rather than size, is found to affect the incidence of variants. Two of the variants were affected by both size and age: the posterior palatin foramen (No. 30) and maxillary foramen I (No. 37). The posterior frontal foramen (No. 8), however, which is highly significantly correlated with age is not correlated with size. Thus, the ontogenetic effect is not necessarily accounted for when testing for size dependence. This is probably partly because large skulls are not necessarily older than small skulls (see Andersen \& Wiig, 1984).

In the present study the number of correlated pairs of variants is higher than could be expected by chance, but the degree of correlation is rather small in most cases, as has also been demonstrated in other studies (e.g. Sikorski, 1982; Sikorski \& Bernshtein, 1984; Pankakoski \& Nurmi, 1986). Non-metrical variants are assumed to be correlated both genetically and environmentally, and as the values of the correlations were generally low, the application of the variants as independent in population studies would not cause any serious distortion of the results (Sjøvold, 1977). In genetical terms this must mean that such variants are the pleiotropic manifestations of many independent developmental 
processes, and that differences in the "spectrum" of epigenetic variation between. individuals reveal variation at a large number of gene loci (Berry \& Berry, 1971; Berry, 1986).

Scoring of variants that are mutually exclusive will inevitably give high correlation coefficients. This latter situation explains the high correlation between the postglenoid foramen and postglenoid foramen separate (Nos. 16 and 17), as scoring of No. 17 as present depends on the presence of the postglenoid foramen. This is partly also the situation fisund on nasale, where four small foramina are scored. Variant No. 44 is: here found to be negatively correlated to both No. $\leq 2(r=-0.244$, $p<0.01)$ and No. $43(r=-0.245, p<0.05)$, which indicates that No. 44 is difficult to separate from No. 42 and No. 43 .

In the present study we have scored a comparatively high number of fisramina, many of which are relatively small. When searching for "good" furamina to score we became aware of the fact that the exact location of some of the smaller foramina, particularly of those on the upper surface of the skull, varied to some degree. Although relatively well delimited in most cases, some of these foramina could in some instances be situated close to other foramina, and in some cases be difficult to delimit as separate foramina. Thus the negative correlation of variant No. 44 to both No. 42 and No. 43 might indicate that these small foramina, which we scored as separate variants, only reflect the variation in a single multistate variant. As most foramina serve as canals for nerves and blood vessels supplying a particular area of the head, the negative correlation could on the other hand implicate that the supply of a particular area of the head might be led through different foramina. If e.g. a geographic pattern in the incidence of such small foramina is found, they may indicate different genetical composition of the populations and thus serve as good population markers. Therefore, until further konwledge about the variation of such variants is accumulated they should be included.

In the present study we found relatively little age variation in the incidence of the variants. However, difficulties in scoring young specimens lead to our belief that studies on e.g. geographic variation, should be based on full-grown individuals only. The Scandinavian lynx grow strongly until approximately one and a half year of age (Andersen \& Wiig, 1984). Several of the foramina were relatively larger in the young animals and thus being easier to score, which might lead to an overrepresentation, in relation to those in skulls of more mature specimens where ossification had proceeded further. On the other hand, the small foramina on the upper surface of the skull could be harder to detect in young animals, as the surface is often porous. In addition, variants 
connected with the ossification of "bridges" or "canals" could be difficult to score. Although they are basically the same foramina, it thus seems wise not to include immature specimens in the samples.

Acknowledgement: We are indebted to E. Pierce for correcting the language.

\section{REFERENCES}

1. Andersen T. \& Wiig $\varnothing ., 1982$ : Epigenetic variation in a fluctuating population of lemming (Lemmus lemmus) in Norway. J. Zool., Lond., 197: 391-404.

2. Andersen T. \& Wiig Ø., 1984: Growth of the skull of Norwegian lynx. Acta theriol., 29: 89-110.

3. Berry A. C. \& Berry R. J., 1971: Epigenetic polymorphism in the primate skeleton. [In: "Comparative genetics in monkeys, apes and man", Ed. A. B. Chiarelli]. Academic Press: 13-41. London.

4. Berry R. J., 1969a: Non metrical skull variation in two Scottish colonies of the Grey seal. J. Zool., Lond., 157: 11-18.

5. Berry R. J., 1969b: History in the evolution of Apodemus sylvaticus (Mammalia) at one edge of its range. J. Zool., Lond., 159: 311-328.

6. Berry R. J., 1975: On the nature of genetical distance and island races of Apodemus sylvaticus. J. Zool., Lond., 176: 293-296.

7. Berry R. J., 1986: Genetics of insular populations of mammals, with particular reference to differentiation and founder effects in British small mammals. Biol. J. Linn. Soc., 28: 205-230.

8. Berry R. J. \& Jakobson M. E., 1975: Ecological genetics of an island population of the House mouse (Mus musculus). J. Zool., Lond., 175: 523-540.

9. Berry R. J., Jakobson M. E. \& Peters J., 1978: The House mice of the Faroe Island: a study in microdifferentiation. J. Zool., Lond., 185: 73-92.

10. Berry R. J. \& Searle A. G., 1963: Epigenetic polymorphism in the rodent skeleton. Proc. zool. Soc., Lond., 140: 577-615.

11. Berry R. J. \& Warwick T., 1974: Field mice (Apodemus sylvaticus) on the Castle Rock, Edinburgh: an isolated population. J. Zool., Lond., 174: 325-331.

12. Brown M. B. \& Benedetti J. K., 1977: On the mean and variance of the tetrachoric correlation coefficient. Psychometrica, 42: 347-355.

13. Dixon W. J., 1981: BMDP Statistical Software 1981. University of California Press: $1-725$, Berkeley.

14. Falconer D. S., 1981: Introduction to quantitative genetics. 2nd ed. Longman: 1-340. London, New York.

15. Grewal M. S., 1962: The rate of genetic divergence of sublines in the C57BL strain of mice. Genet. Res., 3: 226-237.

16. Grüneberg H., 1963: The pathology of development. Blackwell: 1-309. London.

17. Hanski I. \& Kuitunen J., 1986: Shrews on small islands: epigenetic variation elucidates population stability. Holarct. Ecol., 9: 193-204.

18. Hartman S. E., 1980: Geographic variation analysis of Dipodomus ordii using nonmetric cranial traits. J. Mammal., 61: 436-448.

19. Kvam T., 1979: Reproduksjonsforhold og populasjonsstruktur hos norsk gaupe Lynx lynx (L.). Univ. Trondheim: 1-72. Trondheim. (Unpubl. cand. real. thesis). 
20. Kvam T., 1983: Age determination in European lynx Lynx l. lynx (L.) based on cranial development. Fauna norv. Ser. A, 4: 31-36.

21. Kvam T., 1984: Age determination in European lynx Lynx l. lynx by incremental lines in tooth cementum. Acta Zool. Fenn., 171: 221-223.

22. Pankakoski E., 1985: Epigenetic asymmetry as an ecological indicator in muskrats. J. Mammal., 66: 52-57.

23. Pankakoski E. \& Nurmi K., 1986: Skull morphology of Finnish muskrats: geographic variation, age differences and sexual dimorphism. Annls. Zool. Fenn., 23: 1-32.

24. Reimers E. \& Nordby $\varnothing$., 1968: Relationship between age and tooth cementum layers in Norwegian reindeer. J. Wildl. Manage., 32: 957-961.

25. Self G. S. \& Leamy L. J., 1978: Heritability of quasicontinuous skeletal traits in a random-bred population of house mice. Genetics, 88: 109-120.

26. Sikorski M. D., 1982: Non-metrical divergence of isolated populations of Apodemus agrarius in urban areas. Acta theriol., 27: 169-180.

27. Sikorski M. D. \& Bernshtein A. D., 1984: Geographical and intrapopulation divergence in Clethrionomys glareolus. Acta theriol., 29: 219-230.

28. Sjøvold T., 1977: Non-metrical divergence between skeletal populations. Ossa, 4, suppl. 1: xii $+1-113$.

29. Sokal R. R. \& Rohlf F. J., 1981: Biometry. 2nd ed. W. H. Freeman and Company: 1-859. San Francisco.

30. Truslove G. M., 1961: Genetical studies on the skeleton of the mouse. XXX. A search for correlations between some minor variants. Genet. Res., 2: 431-438 .

31. Wiig $\varnothing$. \& Andersen T., 1986: Sexual size dimorphism in the skull of Norwegian lynx. Acta theriol., 31: 147-155.

32. Wiig $\varnothing$. \& Lie R. W., 1979: Metrical and non-metrical skull variations in Norwegian Wild mink (Mustela vison Schreber). Zool. Scr., 8: 297-300.

33. Wiig $\varnothing$. \& Lie R. W., 1984: An analysis of the morphological relationships between the Hooded seals (Cystophora cristata) of Newfoundland, the Denmark Strait, and Jan Mayen. J. Zool., Lond., 203: 227-240.

Received 20 February 1987, Accepted 4 September 1987.

$\varnothing y$ stein WIIG i Trond ANDERSEN

\section{NIEMETRYCZNA ZMIENNOSC CZASZKI RYSIA Z NORWEGII}

\section{Streszczenie}

Zbadano zmienność 53 cech niemetrycznych czaszki rysia (50 samic i 50 samców) Lynx lynx (Linnaeus, 1758) z Norwegii (Ryc. 1). Opisano analizowane cechy oraz zakresy ich zmienności (Tabela 1). Tylko 50\% cech wykazywało znaczącą zależność między występowaniem na prawej i lewej stronie czaszki (Tabela 2). Asymetria $\mathrm{w}$ występowaniu cech niemetrycznych przemawia za oddzielnym rozpatrywaniem każdej ze stron. W niniejszej pracy analizowano cechy lewej strony. Zbadano zależność ich występowania od plci, wielkości i wieku osobników, lecz tylko niewielka liczba cech wykazywała takie zależności (Tabele 3 i 4). Obliczono korelacje między parami cech niemetrycznych (1378 par). Dla 107 par $(7,8 \%)$ korelacja ta była istotna. 